\title{
DIGGER WASP FAUNA (INSECTA, HYMENOPTERA, SPHECIDAE, CRABRONIDAE) OF LA PALMA (CANARY ISLANDS) - A SURVEY WITH DESCRIPTION OF A NEW SPECIES
}

\author{
T. Ljubomirov ${ }^{1}$
}

\begin{abstract}
A survey of the digger wasp fauna of La Palma (Canary Islands) is made. Eleven species are confirmed as present and five of them -Liris nigricans nigricans (Walker, 1871), Miscophus eatoni E. Saunders, 1903, Tachysphex nitidus (Spinola, 1806), Solierella insidiosa de Beaumont, 1964, and Nitela laevigata sp. n.- are recorded for the first time for the fauna of La Palma. A brief evaluation of the digger wasp species richness of La Palma is provided.
\end{abstract}

Key words: Hymenoptera, Sphecidae, Crabronidae, biodiversity, La Palma, Canary Islands.

\section{Resumen}

\section{La fauna de Crabronidae y Sphecidae (Insecta, Hymenoptera) de la isla de La Palma (islas Canarias) - Una aproximación que incluye la descripción de una especie nueva}

Se presenta un estudio de la fauna de Crabronidae y Sphecidae de la isla de La Palma (Islas Canarias). Se considera probada la presencia de once especies, cinco de las cuales -Liris nigricans nigricans (Walker, 1871), Miscophus eatoni E. Saunders, 1903, Tachysphex nitidus (Spinola, 1806), Solierella insidiosa de Beaumont, 1964 y Nitela laevigata sp. n.- se registran por vez primera para la fauna de La Palma. Se adjunta una breve evaluación de la riqueza específica de ambas familias en la isla.

Palabras clave: Hymenoptera, Sphecidae, Crabronidae, biodiversidad, La Palma, Islas Canarias.

\section{Introduction}

The archipelago of the Canary Islands was formed during various volcanic episodes and is nowadays composed of seven main islands. Amongst them La Palma, having a total surface area of 706 square kilometres, is one of the youngest and most remote from the mainland. Therefore, would be expected to have an impoverished fauna compared with the rest of the islands of the archipelago

\footnotetext{
Institute of Zoology. Bulgarian Academy of Sciences. 1, Tzar Ossvoboditel Boulevard. Sofia, 1000. Bulgaria. e-mail: tljubomirov@zoology.bas.bg
} 
(Borges \& Brown, 1999). The digger wasp fauna (families Sphecidae and Crabronidae) confirmed as present in the island so far is no exception to that rule - one species of Sphecidae and five species of Crabronidae are found to inhabit the island of $\mathrm{La}$ Palma against a total of seven Sphecidae and fiftytwo Crabronidae species found to occur in the Canary Islands (Hohmann et al., 1993; SchmidEgger, 2002; Smit, 2007). In the present work are summarized the previous records of Sphecidae and Crabronidae from La Palma and also new data is added for six species, one of which is here described as new.

\section{Material and methods}

The original material on which the present study is based comes from the project on the invertebrate fauna of the Caldera de Taburiente National Park, in the island of La Palma, "Convenio de Cooperación Parques Nacionales-CSIC Inventario y estudio de la fauna invertebrada del P. N. de la Caldera de Taburiente". A total of 156 specimens of Crabronidae and one specimen of Sphecidae have been examined. The material was obtained by two methods -Malaise trapping and Moericke trapping-, between July 1999 and July 2001 by Teresa Domingo-Quero at six places in the Caldera de Taburiente National Park (Domingo-Quero et al., 2003). The material is deposited in the Museo Nacional de Ciencias Naturales, Madrid (MNCN) and Institute of Zoology, Sofia (IZS).

The morphological terms adopted for the descriptions of the new species were mostly taken from Bohart \& Menke, 1976 (for episternal sulcus, hypersternaulus, hypoepimeral area, prepectus and dorsal, lateral, and hind surfaces of the propodeum), Gayubo \& Felton, 2000 (for midclypeal carina, frontal hollow, frontal mark, transversal sulcus of collar and the microreticulate sculpture of the tegument), and Valkeila, 1974 (for punctiform pits on the anterior margin of the scutellum). Reference is made to metasomal terga and sterna, instead of abdominal (gastral) terga and sterna, and to toruli instead of antennal sockets, respectively. The term mesopleurosternum is here used to designate the area below the hypersternalulus and the ventral surface of the mesopleuron. Micropunctures refere to the body punctures having a diameter smaller than 0.1 times the midocellar diameter.

A Philips SEM-515 scanning electron microscope was used to take the photographs of some body parts of three Nitela species.
Abbreviations used are: AOD - midocellar diameter; POL - shortest distance between the hind ocelli; OOL - shortest distance between the compound eye and its respective hind ocellus; DOA shortest distance between the inner ocular orbits at the level of the middle ocellus; DOT - shortest distance between the inner ocular orbits at the level of the dorsal margin of the toruli.

\section{List of the digger wasp species of La Palma}

Family Sphecidae Latreille, 1802

Podalonia tydei tydei (Le Guillou, 1841)

Podalonia tydei tydei: Hohmann et al., 1993: 204 (summary of the previous literature records from 1954 to 1979 with five new locality records from La Palma added).

RECORDS: 28RBS2177-1, Parque Nacional de la Caldera de Taburiente: Roque de la Cumbrecita, 1377m, 29, VI-6, VII, 2000, Malaise trap - $1 \sigma^{7}$.

\section{Family Crabronidae Latreille, 1802}

\section{Bembix flavescens flavescens $\mathrm{F}$. Smith, 1856}

Bembix flavescens: Hohmann et al., 1993: 252 (summary of the previous literature records from 1893 to 1968 with seven new locality records from La Palma added).

\section{Cerceris concinna Brullé, 1839}

Cerceris concinna: Hohmann et al., 1993: 255 (summary of the previous literature records from 1924 to 1978 with five new locality records from La Palma added).

\section{Liris (Leptolarra) micans (Spinola, 1806)}

Liris atrata: Hohmann et al., 1993: 218 (summary of the previous literature records from 1954 to 1978 with one new locality record from La Palma added).

\section{Liris (Leptolarra) nigricans nigricans (Walker, 1871)}

RECORDS: 28RBS1980-1, Parque Nacional de la Caldera de Taburiente: Playa del Río Taburiente, 750 m, 30, VII-10, VIII, 1999, Malaise trap - $20^{7} \sigma^{\top}, 9-18, X, 1999$, Malaise trap - 1 ㅇ.

Tachysphex nitidus (Spinola, 1806)

RECORDS: 28RBS1780-2, Parque Nacional de la Caldera de Taburiente: Barranco de las Traves, 1068 m, 5-13, VI, 2000, Malaise trap - 1 우, 20-27, VI, 2000, Malaise trap - 3 우우, 25, VII-3, VIII, 2000, Malaise trap - $1 \sigma^{7}, 5$ 우 우 28RBS1980-1, Parque Nacional de la Caldera de Taburiente: Playa del Río Taburiente, $750 \mathrm{~m}, 10-18, \mathrm{X}, 1999$, Malaise trap - $1 \sigma^{7}, 15-21$, II, 2000, Malaise trap - $1 \sigma^{7}, 1$ ᄋ , 20-27, III, 2000, Moericke trap -1 오, 27, VI-10, VII, 2000, Malaise trap - 1 ㅇ, 27, VI10, VII, 2000, Moericke trap - 1 \%, 7-14, VIII, 2000, Moericke trap - 1 ㅇ, 14-22 VIII, 2000, Malaise trap - $10^{x}$; 
28RBS2077-3, Parque Nacional de la Caldera de Taburiente: Lomo de las Chozas, 1277 m, 1-7, VI, 2000, Malaise trap - 1 우, 14-21 VI, 2000, Moericke trap - $1 \sigma^{7}, 5-12$, VII, 2000, Malaise trap - 1 우, $\sigma^{7}, 5-12$, VII, 2000, Moericke trap - $1 \sigma^{7}$; 28RBS2177-1, Parque Nacional de la Caldera de Taburiente: Roque de la Cumbrecita, 1377 m, 31, VII-4, VIII, 1999, Malaise trap - $40^{\top} \sigma^{\top}, 1$ ㅇ, 29, IX-6, X, 1999, Malaise trap 2 우 ㅇ, 8-15, III, 2000, Malaise trap - $1 \sigma^{7}, 8-15$, III, 2000, Moericke trap - $1 \sigma^{\pi}, 15-22$, III, 2000, Moericke trap - 1 ᄋ, 25, V-1, VI, 2000, Malaise trap - 3 우, 1-7, VI, 2000, Malaise trap - 2 우, 7-15, VI, 2000, Malaise trap - $2 \sigma^{\top} \sigma^{\top}, 1$ ㅇ, 1521, VI, 2000, Malaise trap - 4 ơ $^{\top}, 6$ 우, 21-29, VI, 2000, Malaise trap - $2 \sigma^{\top} \sigma^{\top}, 29$, VI-6, VII, 2000, Malaise trap - 2 $0^{\top} \sigma^{7}, 4$ 우 우, 6-12, VII, 2000, Malaise trap - $10^{\top}, 1$ 오, 12-19, VII, 2000, Malaise trap - 3 우, 12-19, VII, 2000, Moericke trap - 1 ○", 9-16, VIII, 2000, Malaise trap - 1 오, 16-24, VIII, 2000, Malaise trap - $1 \sigma^{7}, 4$ 우, 5-13, IX, 2000, Malaise trap - 2 우 우, 13-20, IX, 2000, Malaise trap - 6 우 우 28RBS20843, Parque Nacional de la Caldera de Taburiente: Roque de Los Muchachos, $2250 \mathrm{~m}, 10-17$ VIII, 2000, Moericke trap - $1 \sigma^{7}$, 7-14, VI, 2001, Moricke trap - 1 오, 14-21, VI, 2001, Malaise trap - 1 o , 14-21, VI, 2001, Moericke trap - 1 ㅇ, 27, VI-4, VII, 2001, Moericke trap - 1 우, 4-11, VII, 2001, Malaise trap - 1 오, 11-15 VII, 2001, Moericke trap - $1 \sigma^{7}, 1$ 오.

\section{Tachysphex unicolor simonyi Kohl, 1892}

Tachysphex unicolor simonyi: Hohmann et al., 1993: 239 (four locality records from La Palma presented).

\section{Miscophus (Miscophus) eatoni E. Saunders, 1903}

RECORDS: 28RBS1780-2, Parque Nacional de la Caldera de Taburiente: Barranco de las Traves, 1068 m, 20-27, VI, 2000, Malaise trap $-1 \sigma^{\pi}, 25$, VII-3, VIII, 2000, Malaise trap -2 우 우 28RBS1980-1, Parque Nacional de la Caldera de Taburiente: Playa del Río Taburiente, 750 m, 10-20, IX, 1999, Malaise trap - 1 우, 10-18, X, 1999, Malaise trap - $1 \sigma^{7}, 1-8$, XI, 1999, Malaise trap - 2 우 ㅇ, 20-29, XI, 1999, Malaise trap - 1 우, 18-24, IV, 2000, Moericke trap - 1 우, 5-13, VI, 2000, Malaise trap - $1 \sigma^{7}, 20-27$, VI, 2000, Malaise trap - 1 ㅇ, 2027, VI, 2000, Moericke trap - 1 \& , 14-22, VIII, 2000, Malaise trap - 2 우 ㅇ; 28RBS2077-3, Parque Nacional de la Caldera de Taburiente: Lomo de las Chozas, 1277 m, 12-21, VI, 2000, Moericke trap - 1 \& , 9-16, VIII, 2000, Moericke trap - $20^{7} \sigma^{\prime \prime}$, 16-24, VIII, 2000, Malaise trap - 2 우, 7-13, IX, 2000, Malaise trap - 1 ㅇ, 7-13, IX, 2000, Moericke trap - 1 우 28RBS2177-1, Parque Nacional de la Caldera de Taburiente: Roque de la Cumbrecita, 1377 m, 31, VII-4, VIII, 1999, Malaise trap - $1 \sigma^{7}, 1$ 우, 1-6, X, 1999, Malaise trap - 1 오, 715, VI, 2000, Moericke trap - $1 \sigma^{7}, 6-12$, VII, 2000, Moericke trap - 1 우, 9-16, VIII, 2000, Malaise trap - $1 \sigma^{\prime}, 4$ 우우, 1624, VIII, 2000, Malaise trap - 2 우.

REMARKS. This species, widespread in the Mediterranean, has been previously reported for the Canary Islands from Tenerife (Hohmann et al., 1993, Schmid-Egger, 2002, among others). The occurrence of $M$. eatoni in La Palma reveals that it has come from the mainland (north west Africa) through Tenerife and has been able to colonize later
La Palma too. M. eatoni has not been recorded from islands close to the mainland, such as Fuerteventura and Lanzarote, up to now. However, if two other "morphospecies" from the Canary Islands, M. guichardi de Beaumont, 1968 and M. nitidior de Beaumont, 1968 prove to be synonyms of M. eato$n i$ then the gradual spreading in a north-west direction of this species will be confirmed, at least for the colonization of Fuerteventura and Gran Canaria. The studied material from La Palma (8 males and 25 females) shows some individual variations regarding the body sculpture which overlap many of the diagnostic characters both of $M$. guichardi and M. nitidior.

\section{Nitela laevigata sp. $\mathbf{n}$.}

TyPe Material. Holotype: male, Spain: Islas Canarias, La Palma, Parque Nacional de la Caldera de Taburiente, 28RBS1980-1, Playa del Río Taburiente, $750 \mathrm{~m}, 25-30$, V, 2000, Malaise trap (MNCN). - Paratypes: 8 males and 14 females: Spain: Islas Canarias, La Palma, Parque Nacional de la Caldera de Taburiente, 28RBS1980-1, Playa del Río Taburiente, $750 \mathrm{~m}:$ 30, VII-10, VIII, 1999, Malaise trap, (1 우) $(\mathrm{MNCN})$; 18-24, IV, 2000, Malaise trap, $\left(1 \sigma^{7}\right)(\mathrm{MNCN}) ; 23-$ 30, V, 2000, Malaise trap, (1 $\sigma^{7}, 1$ 우 $)(\mathrm{MNCN}) ; 6-13$, VI, 2000, Moericke trap, (1 우) (MNCN); 20-27, VI, 2000, Malaise trap, (1 $\left.\sigma^{7}\right)(\mathrm{MNCN}) ; 20-27, \mathrm{VI}, 2000$, Moericke trap, (1 우) (IZS); 20-27, VI, 2000, Moericke trap, (1 o, 2 우 우) $(\mathrm{MNCN}) ; 27, \mathrm{VI}-10$, VII, 2000, Malaise trap, (1 $\left.\sigma^{7}\right)(\mathrm{MNCN})$; 27, VI-10, VII, 2000, Moericke trap, (2 우 우) (MNCN); 10-17, VII, 2000, Moericke trap, (1 \& ) (IZS); 10-17, VII, 2000, Moericke trap, (4 우) (MNCN); 14-22, VIII, 2000, Malaise trap, (1 ণ", 1 ᄋ ) (MNCN); 10-18, IX, 2000, Malaise trap, (1 $\left.\sigma^{7}\right)$ (IZS); 10-18, IX, 2000, Malaise trap, (1 $\left.\sigma^{7}\right)(\mathrm{MNCN})$.

DESCRIPTION. Male. Head subrounded (figure 1). Labrum lamelliform, rectangular, its free margin largely concave, visible beyond the clypeal margin. Clypeus (figure 2): slightly prolonged in the middle portion, free margin apically slightly inflected backward to the oral cavity; clypeal disc shiny, bearing ill defined punctures and subappressed silvery setae 0.6-1.0 x AOD in length, directed downward, not concealing the integument; midclypeal carina sharp, distanced from the clypeal free margin by about $0.8 \times$ AOD, reaching the frontal mark; clypeal disc with the middle portion convex; shortest distance between clypeal free margin and ventral margin of torulus $0.8 \times$ AOD. Frontal hollows shallow, shiny, covered with sparse setae similar to the setae on the clypeal disc; face above frontal hollows shiny and densely punctate (puncture diameter 0.2 x AOD, punctures separated by $1.0-1.2 \mathrm{x}$ their own diameter and slightly coalescent into longitudinal wrinkles, toward the vertex these wrinkles 

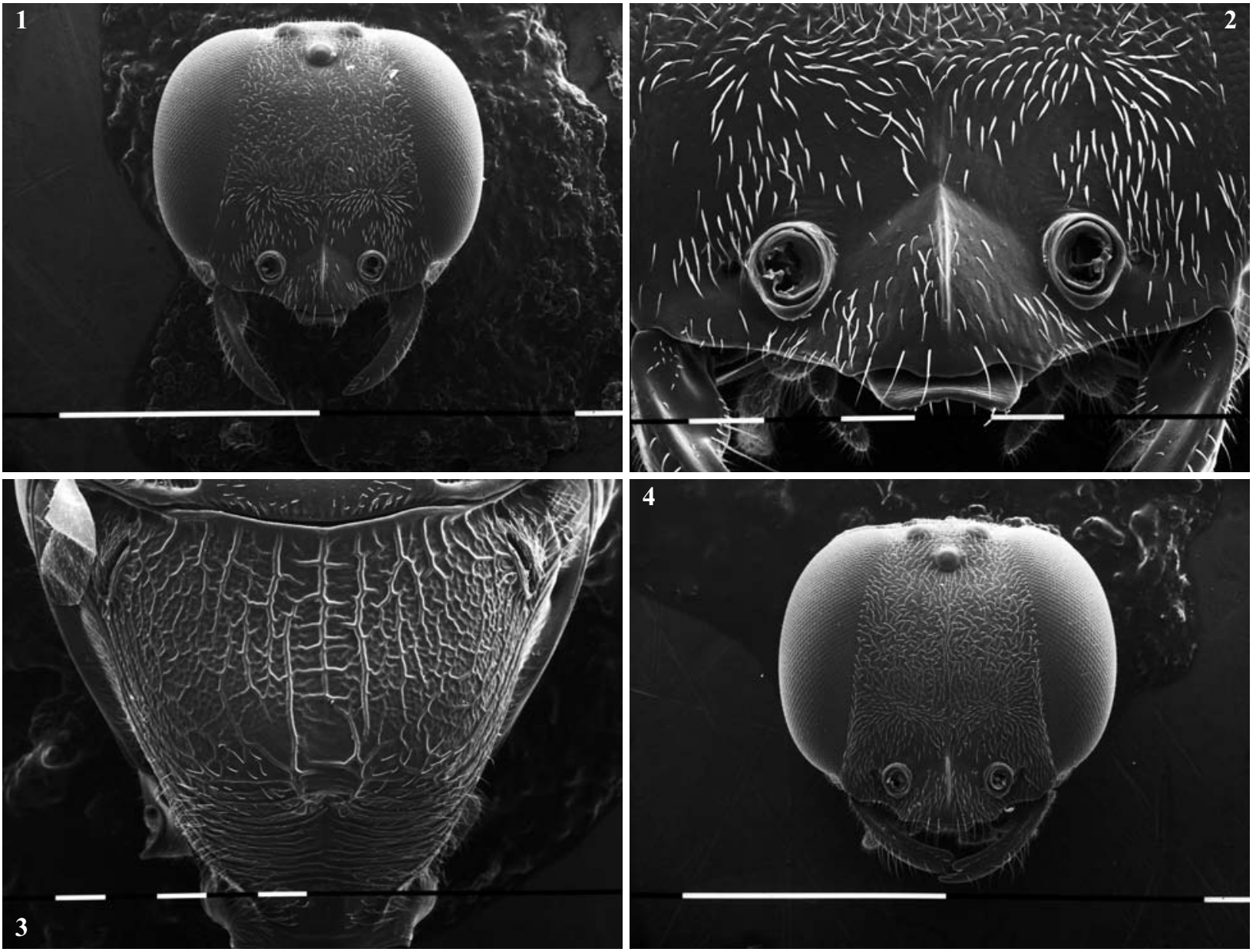

Figs. 1-4.- Nitela laevigata male paratype: 1) head frontal view, 2) clypeus frontal view, 3) propodeum dorsal view. Nitela laevigata female paratype: 4) head, frontal view. Scale bar: $1 \mathrm{~mm}$ (figs. 1 y 4); 0,1 mm (figs. 2 y 3 ).

Figs. 1-4.- Nitela laevigata paratipo macho: 1) vista frontal de la cabeza, 2) vista frontal del clípeo, 3) vista dorsal del propodeo. Nitela laevigata paratipo hembra: 4) vista frontal de la cabeza. Escala: $1 \mathrm{~mm}$ (figs. 1 y 4); 0,1 mm (figs. 2 y 3 ).

disappear and the punctures are sparser). Vertex: sculpture identical with this on the upper part of the face, the areas adjacent laterally to the hind ocelli glabrous, without punctures. POL:OOL $=2.1$. Gena generally punctatorugulose, in its dorsal half the wrinkles are stronger and denser, in the ventral half they are rather weak and mixed with sparse punctures $0.2 \times$ AOD in diameter and 1.0-1.4 $\mathrm{x}$ diameter apart. Compound eyes with fine sparse short white pubescence; the outline of the eyes in frontal view slightly convex; inner orbits converging above $(\mathrm{DOA}: \mathrm{DOT}=0.67, \mathrm{n}=9$ ). Mandibles: evenly curved; inner margin without a tooth. Antennae: first flagellomere twice as long as the pedicel.
Pronotum: pronotal collar matt to slightly shiny, densely transversely wrinkled, accompanied by ill defined small punctures between the wrinkles; transversal sulcus of collar well defined, its bottom glabrous (but feebly uneven in the anterior half), shiny. Mesoscutum: disc with shallow well defined punctures (puncture diameter $0.2 \times \mathrm{AOD}$, punctures separated by 2.0-3.0 $\mathrm{x}$ their own diameter) and fine transverse ridges which become stronger apically and are obliquely directed laterally from the middle of the posterior mesonotal margin; mesoscutal lateral sulcus with well defined cross carinae, its inner border ill defined. Scutellum: punctiform pits on its anterior margin, deeper and stronger in the 

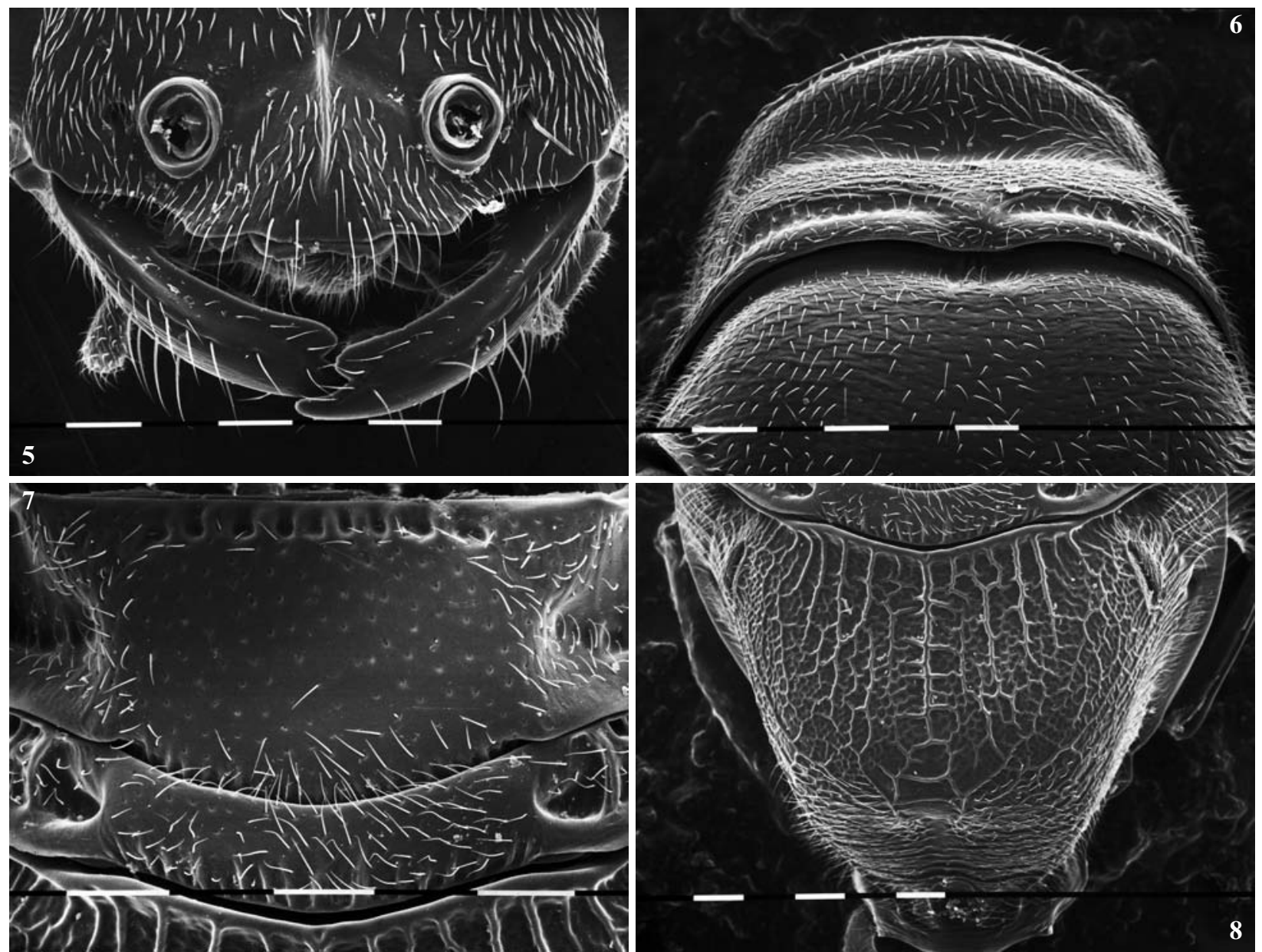

Figs. 5-8.- Nitela laevigata female paratype: 5) clypeus frontal view; 6) transversal sulcus of collar, dorsal view; 7) scutellum \& metanotum, dorsal view, 8) propodeum, dorsal view. Scale bar: $0.1 \mathrm{~mm}$.

Figs. 5-8.- Nitela laevigata paratipo hembra: 5) vista frontal del cípleo; 6) vista dorsal del surco transverso del collar; 7) vista dorsal del escudete y metanoto; 8) vista dorsal del propodeo. Escala: 0,1 mm.

middle, laterally smaller and separated from the anterior scutellar margin; scutellar disk shiny, with shallow sparse punctures (puncture diameter $0.1 \mathrm{x}$ AOD, punctures separated by 4.0-6.0 x their own diameter), its anterior part longitudinally wrinkled. Mesopleuron: episternal sulcus and hypersternaulus shallow, weakly defined; hypersternalulus ending well before the mid coxa, inconspicuously crenulate; mesopleurosternum shiny, feebly, sparsely and irregularly punctured (puncture diameter 0.1-0.2 x AOD, punctures separated by 3.0-5.0 x their own diameter); prepectus and lower half of hypoepimeral area sculptured almost as the mesopleurosternum but punctures a little stronger and spaces between them uneven and less shiny; upper half of hypoepimeral area glabrous and shiny apically with small, sparse punctures (puncture diameter $0.1 \times$ AOD, punctures separated by $4.0-6.0 \times$ their own diameter). Metanotum: disc shiny, sculpture similar to that of the posterior part of the mesoscutum. Propodeum: dorsal surface with low longitudinal carinae which disappear posterolaterally and with lower secondary carinae crossing the longitudinal ones, the spaces between them matt to moderately shiny and uneven, without punctures (figure 3); lateral surface with low longitudinal carinae, interspaces uneven, weakly wrinkled, matt; hind surface with transverse carinae and une- 
ven, matt to moderately shiny interspaces; dorsal, lateral and hind surface not delimited by carinae. Metasoma: tergum I shiny, glabrous, in its anterior half with well defined, shallow, sparse punctures (puncture diameter $0.1 \times$ AOD, punctures separated by 5.5-7.0 $\mathrm{x}$ their own diameter), in its posterior half these punctures are more or less arranged into a preapical transverse row behind which the tegument is finely transversally wrinkled; terga II-IV are sculptured similary to the first but the punctures are less defined and each tergum has its basal third covered by transverse, fine wrinkles; sterna with well defined minute transverse wrinkles and ill defined micropunctures; apical part of sternum VIII comparatively wide, bluntly pointed at the apex. Body and appendages black with the following parts faded to brownish or reddish: light brown maxillary and labial palps, dark brown wing veins, brownish red labrum, dark red mandibular apex. Length: 3.7-4.6 $\mathrm{mm}$ (holotype $4.2 \mathrm{~mm}$ ).

Female. Head subrounded (figure 4). Labrum: rectangular in shape, free margin visible beyond the clypeal margin, slightly emarginated in the middle. Clypeus (figure 5): free margin trilobate, median lobe $1.6 \mathrm{x}$ longer than the lateral lobe along the clypeal free margin, protruding by about $0.7 \mathrm{x}$ AOD from the lateral lobes, in the middle bituberculate, the distance between the tubercles is $1.8 \mathrm{x}$ AOD, from each tubercle originates an ill defined carina running dorsomedially over the clypeal disc, the two carinae converge at the level of the ventral margin of the torulus merging dorsally into a much more clearly defined midclypeal carina which extends up to the level of the dorsal margin of the frontal hollow and does not reach the frontal mark; the triangular area formed by the carinae in the lower part of the median lobe is slightly concave, shiny, without pubescence; shortest distance between clypeal free margin and ventral margin of torulus $1.2 \mathrm{x}$ AOD, the rest of the clypeal disk shiny, with ill defined fine punctures and sparse, downward-pointing appressed silvery setae. Frontal hollows glabrous, with indistinct micropunctures, covered with sparse appressed white setae; face above frontal hollows shiny, densely and regularly punctate (puncture diameter $0.3 \mathrm{x}$ AOD, punctures separated by $0.8-1.5 \mathrm{x}$ their own diameter, the punctures are rather sparse toward the middle ocellus), covered with sparse white erect setae $1.4 \mathrm{x}$ AOD in length. Vertex: shiny, distinctly punctured (puncture diameter $0.2 \times$ AOD, punctures separated by 1.0-1.4 x their own diameter). POL:OOL $=1.7$. Gena shiny, the tegument uneven with well-defined fine punctuation (puncture diameter $0.1 \times \mathrm{AOD}$, punctures separated by $0.7-1.3 \times$ their own diameter). Compound eyes with fine sparse short white pubescence; the outline of the eyes in frontal view slightly to moderately convex; inner orbits converging above $($ DOA:DOT $=0.71, \mathrm{n}=14)$. Mandibles: evenly curved, not tapering toward the apex; inner margin with a large blunt preapical tooth. Antennae: first and second flagellomeres equal in length, each one of them slightly longer than the pedicel. Pronotum: with evanescent punctures dorsally; pronotal collar with dense fine transverse wrinkles; transversal sulcus of collar (figure 6) shallow, its bottom matt to moderately shiny with evanescent fine reticulation. Mesoscutum: the disc shiny, evenly punctured (puncture diameter $0.2 \times \mathrm{AOD}$, punctures separated by $1.0 \mathrm{x}$ their own diameter), with fine transverse ridges; mesoscutal lateral sulcus ill defined. Scutellum: punctiform pits in its anterior margin equal in size and depth, (figure 7); scutellar disk shiny, with shallow even punctures (puncture diameter 0.1 x AOD, punctures separated by 1.5 $2.0 \times$ their own diameter); posterior margin with very fine, short longitudinal carinae. Mesopleuron: episternal sulcus and hypersternaulus shallow, weakly impressed upon the mesopleural surface, feebly crenulate; prepectus and mesopleurosternum densely punctured (puncture diameter 0.4-0.5 $\mathrm{x}$ AOD, punctures separated by $0.2-0.8 \mathrm{x}$ their own diameter); lower half of hypoepimeral area sculptured in the same way but punctures sparser; upper half of hypoepimeral area glabrous and shiny, its tegument microreticulate. Metanotum: disc shiny, with ill defined micropunctures in its anterior two thirds and longitudinally wrinkled in its posterior third. Propodeum: all surfaces with rather weak carinae, matt to shiny, unevenly sculptured; dorsal surface with few bigger carinae basomedially and with minute secondary (transverse and oblique) carinae crossing the longitudinal ones (figure 8); lateral surface with weak longitudinal carinae; dorsal, lateral and hind surface not delimited by carinae. Metasoma: terga shiny, with clear sparse micropunctures in their basal half (punctures separated by $5.0-10.0 \mathrm{x}$ their own diameter) and with singular ones in the apical half of terga I and II forming preapical rows there; sterna with ill defined micropunctures and fine minute wrinkles; sternum II with basal transverse concavity. Body and appendages black with the following parts faded: light brown maxillary and labial palps, brown wing veins, brownish red labrum, rusty red mandibular apex. Length: 4.1-4.9 mm. 

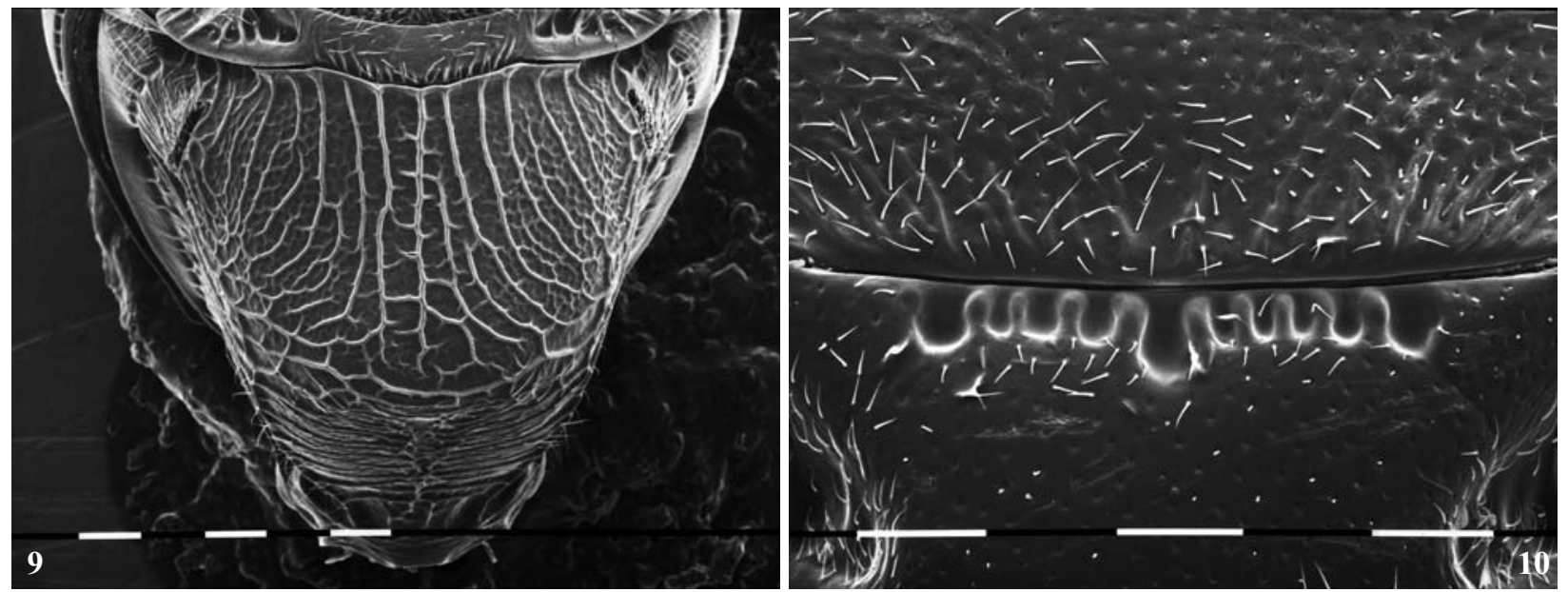

Figs. 9-10.- 9) Nitela spinolae female Italy, Sangro river valley, propodeum. 10) Nitela truncata female Bulgaria, Kameno Pole village, hind margin of mesoscutum \& punctiform pits in anterior margin of scutellum dorsal view. Scale bar: $0.1 \mathrm{~mm}$.

Figs. 9-10.- 9) Nitela spinolae hembra del valle del río Sangro, Italia, vista dorsal del propodeo. 10) Nitela truncata hembra aldea de Kameno Pole, Bulgaria, vista dorsal del borde posterior del mesoscutum y fóveas puntiformes en el borde anterior del scutellum. Escala: 0,1 mm.

VARIATION. Males: in some specimens the middle portion of the clypeal disc in its preapical part is more or less punctured, the lower half of the hypoepimeral area in front is more or less longitudinally wrinkled, and the tibiae and tarsi are dark brown. Females: oblique carinae in preapical part of the middle portion of clypeal disk sometimes evanescent, the area defined between them being at the same time ill defined and matt, mesoscutal transverse ridges sometimes present only laterally.

Etymology. The specific epithet is derived from the Latin adjective laevigata - polished, with reference to the conspicuously smooth mesopleuron and propodeum, the two main recognition characters of this species. Palma.

GeOgRAPHIC Distribution. Canary Islands: La

DisCUSSION. Nitela laevigata is unique in that on its glabrous propodeum there are no carinae delimiting its dorsal, lateral and hind surface, unlike the other known European species of Nitela, which have a strongly rigged propodeum. In fact, some females of $N$. spinolae have weakly sculptured propodeum, but even in those cases the sculpture is stronger than that of $N$. laevigata (figure 9). The male has further distinctive characters: midclypeal carina sharp and reaching the frontal mark, combined with shallow, shiny frontal hollows which are not concealed by hairs, a well defined transversal sulcus of the collar with a glabrous bottom, and the pointed apex of sternum VIII. The female can be recognized also by the following combination of characters: punctiform pits in the anterior margin of scutellum equal in size and in depth, not present laterally at the anterior scutellar margin, glabrous and shiny hypoepimeral area, and longitudinally wrinkled posterior third of metanotum. Morphologically, the closest species to $N$. laevigata is $N$. truncata. The male of $N$. laevigata differs from it by the pointed apex of sternum VIII; the female of $N$. laevigata has no oblique wrinkles on the posterior mesoscutal margin, whereas in $N$. truncata such wrinkles are clearly defined (figure 10); the punctiform pits in the anterior scutellar margin are equal in size and depth in N. laevigata, whereas in N. trunca$t a$ there are three bigger pits amongst the others in the pit row (figure 10); the first flagellomere in N. laevigata is almost equal in length to the pedicel, whereas in N. truncata it is twice as long as the pedicel. The male of $N$. laevigata is similar to the males of $N$. fallax and N. spinolae in the shape of the free clypeal margin and the structure of the anteromedial part of the clypeal disc and the mesopleurosternum. It differs from $N$. fallax in having much finer sculpture on the whole body and from N. spinolae in having a wider face, no rugosity on the mesopleurosternum, and sparser punctuation in the basal metasomal terga. The female of $N$. laevigata is similar to the females of $N$. 
fallax and $N$. spinolae by the shallow, sculptured transversal sulcus of the collar. It differs from $N$. fallax in having no wrinkles on the face and from $N$. spinolae in having glabrous frontal hollows, sparsely covered with setae and a midclypeal carina which does not extend to the frontal mark. The female of $N$. laevigata reminds one of the Nitela specimen noted by Valkeila (1974: 82) but unassigned at the species level, especially by the shape of the free clypeal margin and flatter propodeal carinae.

\section{Nitela spp.}

Nitela spp.: Hohmann et al., 1993: 228 (summary of the previous literature records from 1968 to 1978).

Solierella canariensis E. Saunders, 1904

Solierella canariensis: Báez et al., 2004: 299.

RECORDS: 28RBS2077-3, Parque Nacional de la Caldera de Taburiente: Lomo de las Chozas, 1297 m, 31, VII-4, VIII, 1999, Malaise trap - 1 o ; 28RBS2077-3, Parque Nacional de la Caldera de Taburiente: Lomo de las Chozas, 1277 m, 6-12, VII, 2000, Moericke trap - $1 \sigma^{7}$; 28RBS2177-1, Parque Nacional de la Caldera de Taburiente: Roque de la Cumbrecita, 1377 m, 17-25, VIII, 1999, Malaise trap - 1 오, 21-29, VI, 2000, Malaise trap - $1 \sigma^{\prime}, 1$ ○, 29, VI-6, VII, 2000, Malaise trap - 1 우, 6-12, VII, 2000, Malaise trap - 1 우, 12-19, VII, 2000, Moericke trap - 1 ㅇ, 9-16, VIII, 2000, Malaise trap - 2 우 ㅇ, 16-24, VIII, 2000, Malaise trap - 1 우.

REMARKS. Noteworthy are the variations in the fore wing venation in this species. One of the males has three submarginal cells on each fore wing, while the other has two submarginal cells on the left fore wing and three on the right one. In females this character varies too - one female has two submarginal cells on each fore wing while the remaining eight females have three submarginal cells on the fore wings.

\section{Solierella insidiosa de Beaumont, 1964}

RECORDS: 28RBS2084-3, Parque Nacional de la Caldera de Taburiente: Roque de Los Muchachos, 2250 m, 4-11, VII, 2001, Moericke trap -1 오 .

Remarks. Soleriella insidiosa is known from Cyprus, Syria, Spain and Portugal so far (Bitsch et al., 2007) and is here recorded for the first time for the Canary Islands. The only female examined from Roque de Los Muchachos has strongly reduced pale markings -only the mandibles in part are marked with yellow. In addition, unlike typical $S$. insidiosa, the lower surface of the front and mid tibiae has a small apical pale spot which occupies an area not bigger than the middle ocellus. Like $S$. insidiosa from the eastern Mediterranean the fema- le from La Palma has the upper half of the hypoepimeral area sparsely punctured and partly shiny, and a comparatively short first flagellomere -the ratio length:width is $3: 2$. Like $S$. insidiosa from Spain the punctuation on the mesoscutum and scutellum is denser -e. g. on the scutellum the punctures are separated by $1.5-1.7 \times$ their own diameter. Probably Giner Marí (1945: 361) has dealt with the female of this species (not described yet at that time) from Gran Canaria.

\section{Trypoxylon attenuatum F. Smith, 1851}

Trypoxylon attenuatum: Hohmann et al., 1993: 242 (summary of the previous literature records).

\section{An evaluation of the digger wasp species richness of La Palma}

Compared with the other six main islands of the Canary Islands La Palma has the poorest digger wasp fauna. This could be explained by applying the hypotheses for the way in which species richness is related to geographical variables in oceanic volcanic islands (Borges \& Brown, 1999). There are four main geographical variables which can affect the species richness in any group of organisms: area, distance from mainland, altitude and geological age. Based on these four variables the following hypotheses have been proposed: 'species-area hypothesis', 'isolation hypothesis', 'altitude range hypothesis' and 'time hypothesis' respectively (Borges \& Brown, 1999). In Table 1 are compared the values of these geographical variables for La Palma and the older islands of the Canary archipelago, Fuerteventura and Lanzarote, and the total number of species and endemics is calculated as well. Regarding this data the total number of Crabronidae of Lanzarote and Fuerteventura is twice that of La Palma or even higher, and the number of Sphecidae is five times larger. The 'species-area hypothesis' predicts that assemblages will be more species rich on larger islands. Fuerteventura and Lanzarote are not much bigger than La Palma and there are no grounds for such a conclusion. The 'altitude range hypothesis' does not support the species impoverishment of the digger wasps of La Palma, since this hypothesis states that island elevation may influence habitat diversity - a greater elevation generates more habitats, thus predicting a positive relationship between maximum elevation and species richness. Fuerteventura and Lanzarote are lower than La Palma in elevation due to the effects of erosion. Further, the proximity 


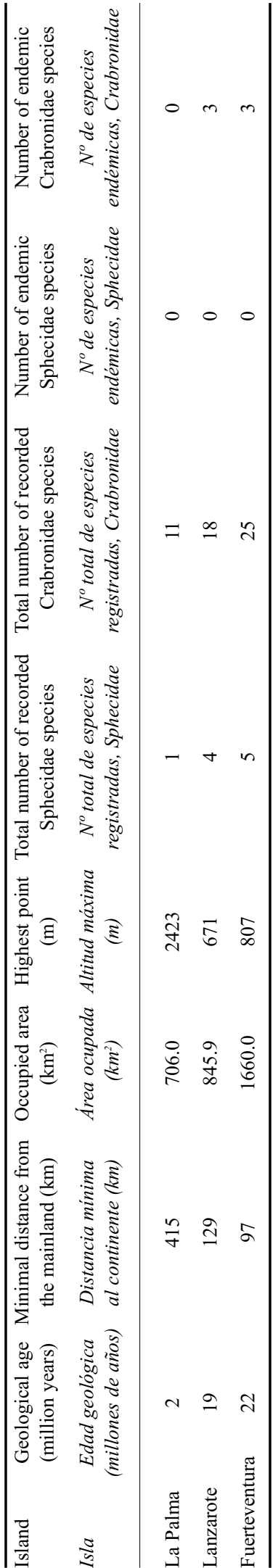

of the Sahara Desert renders them the driest islands in the archipelago, with most of their habitats being dry lowlands. La Palma, on the other side, is occasionally affected by winds from the Sahara Desert and in most cases offers more moisture and temperate habitats but also has dry and warm areas in its southern part. The last two hypotheses, however, strongly support the low number of Sphecids and Crabronids in La Palma and the absence of endemics as well. The 'isolation hypothesis' predicts that, for a given group of organisms, an island located near the source mainland should have more species than a remote oceanic island and at the same time, a remote island may have more endemic species than a less isolated island. In La Palma no endemic species have been discovered. Nitela laevigata is known at present from this island only, but there is strong evidence to presume that it could be found on other islands of the archipelago (de Beaumont, 1968). The relative youth of this island would explain the zero percentage of endemic species of digger wasps. In Fuerteventura and Lanzarote the percentage of endemic species is low but it is not zero. The three species mentioned as endemics there, Harpactus guichardi (de Beaumont, 1968), Miscophus guichardi (de Beaumont, 1968) and Pseudomicroides elvirae (Gayubo, 1982) occur on both islands. The 'time hypothesis' proposes that species accumulate over time and the diversity of a region is therefore directly related to its age. Such a remote island as La Palma, with a geological age of about two million years, has not been saturated with species due to the fact that there has been insufficient time for colonization and speciation. Thus, it is not surprising that we find (apart from the intensity of studies) such a low number of species on this island. They belong to three groups of colonizers: 1) widely distributed in the Palearctic region (or even outside it): Podalonia tydei tydei, Liris micans, Tachysphex nitidus, Trypoxylon attenuatum; 2) widespread in the Mediterranean: Bembix flavescens flavescens, Miscophus eatoni, Solierella insidiosa; 3 ) endemic to the Canary Islands and having their origin in some of the older islands: Cerceris concinna, Tachysphex nitidus simonyi, Nitela laevigata, Solierella canariensis.

\section{ACKNOWLEDGMENTS}

I greatly appreciate the help of Dr. Miguel Angel Alonso Zarazaga with the loan of the material which was accumulated in the course of the project on the invertebrate fauna of the Caldera de Taburiente National Park, "Convenio de 
Cooperación Parques Nacionales-CSIC Inventario y estudio de la fauna invertebrada del P. N. de la Caldera de Taburiente". Access to this material was made available during my stay at the MNCN, supported by the European Union-funded Integrated Infrastructure Initiative grant - "SYNTHESYS" (Grant ES-TAF-2756 for museum work with the Hymenoptera collection).

\section{References}

BÁez, M., Koponen, M., García, A. \& Martín, E., 2004. Hymenoptera. In: Izquierdo, I., Martín, J.L., Zurita, N. \& Arechavaleta, M. (eds.). Lista de especies silvestres de Canarias (hongos, plantas y animales terrestres). Consejería de Medio Ambiente y Ordenación Territorial, Gobierno de Canarias. La Laguna: 281-300.

Bitsch, J., Dollfuss, H., Boucek, Z., Schmidt, K., Schmid-Egger, C., Gayubo, S. F., Antropov, A. \& BArbIER, Y., 2007. Faune de France. France et régions limitrophes. 86. Hyménoptères Sphecidae d'Europe occidentale. Volume 3. Fédération Française des Sociétés de Sciences Naturelles. (séconde edition). Paris. 479 pp.

Bohart, R. \& Menke, A., 1976. Sphecid wasps of the world. A generic revision. University of California Press. Berkeley. IX + 695 pp.

Borges, P. \& Brown, V., 1999. Effect of island geological age on the arthropod species richness of Azorean pastures. Biological Journal of the Linnean Society, 66: 373-410.

DE Beaumont, J., 1968. Sphecidae des Îles Canaries (Hymenoptera). Bulletin of the British Museum (Natural History). Entomology, 21: 245-278.

Domingo-Quero, T., Alonso-Zarazaga, M., SÁnchezRuiz, A., Araujo Armero, R., Navas Sánchez, A., SÁnchez Moreno, S., García Becerra, R., Nebreda, M., SÁnchez Ruiz, M., Fontal-Cazalla, F. \& Nieves-AldREY, J. L., 2003. Inventariando la Biodiversidad en el Parque Nacional de la Caldera de Taburiente (La Palma, Islas Canarias, España): novedades científicas. Graellsia, 59(2-3): 45-68.
Gayubo, S. F. \& Felton, C., 2000. The European species of the genus Nitela Latreille, 1809 (Hymenoptera: Sphecidae). Annales de la Société Entomologique de France (Nouvelle Série), 36: 291-313.

GINER MARÍ, J., 1945. Resultados cientificos de un viaje entomológico al Sáhara español y zona oriental del Marruecos español. Familias Sphecidae y Mutillidae (Hym. Sphec. y Mut.). Eos, [1944], 20: 351-385.

Hohmann, H., La Roche, F., Ortega, G. \& Barquín, J., 1993. Bienen, Wespen und Ameisen der Kanarischen Inseln. Veröffentlichungen aus dem ÜberseeMuseum Bremen. Naturwissenschaften 12. Volume I: 1-465 \& plates I-XII; Volume II: 487-899.

SCHMID-EGger, C., 2002. The species of Miscophus Jurine 1807 from the Canary Islands with description of a new species (Hymenoptera: Apoidea: Crabronidae). Linzer biologische Beiträge, 34: 1627-1638.

SMIT, J., 2007. New wasps and bees for the fauna of the Canary Islands (Hymenoptera, Aculeata). Linzer biologische Beiträge, 39: 651-656.

VAlKeILA, E., 1974. Nitela spinolai Latr. s. auct. (Hym., Sphecoidea, Larridae): A confusion of two European species. Annales Entomologici Fennici, 40: 75-85.
Recibido, 15-V-2008 Aceptado, 23-X-2008 Publicado, 29-XII-2008 